\title{
A Bibliometric Analysis of Atopic Dermatitis Research over the Past Three Decades and Future Perspectives
}

\author{
Dongwon Kim ${ }^{1}$, Younbyoung Chae ${ }^{1,2}\left(\mathbb{D}, \mathrm{Hi}\right.$-Joon Park ${ }^{1,2}$ and In-Seon Lee ${ }^{1,2, *(\mathbb{C}}$ \\ 1 College of Korean Medicine, Kyung Hee University, Seoul 02447, Korea; dwtuna96@khu.ac.kr (D.K.); \\ ybchae@khu.ac.kr (Y.C.); acufind@khu.ac.kr (H.-J.P.) \\ 2 Acupuncture \& Meridian Science Research Center, Kyung Hee University, Seoul 02447, Korea \\ * Correspondence: inseon.lee@khu.ac.kr; Tel.: +82-2-961-2204
}

check for

updates

Citation: Kim, D.; Chae, Y.; Park, H.-J.; Lee, I.-S. A Bibliometric Analysis of Atopic Dermatitis Research over the Past Three Decades and Future Perspectives. Healthcare 2021, 9, 1749. https://doi.org/ $10.3390 /$ healthcare 9121749

Received: 22 November 2021 Accepted: 14 December 2021 Published: 17 December 2021

Publisher's Note: MDPI stays neutral with regard to jurisdictional claims in published maps and institutional affiliations.

Copyright: (c) 2021 by the authors. Licensee MDPI, Basel, Switzerland. This article is an open access article distributed under the terms and conditions of the Creative Commons Attribution (CC BY) license (https:// creativecommons.org/licenses/by/ $4.0 /)$.

\begin{abstract}
Atopic dermatitis (AD) has been increasing in prevalence over the past few decades; however, AD has never been analyzed using a bibliometric approach. We searched for AD studies in the dermatology and allergy category of the Web of Science and SCOPUS databases using the keywords "atopic dermatitis", "eczema", and "atopy". In total, 53,460 documents were retrieved. We analyzed annual publication trends and performed keyword and co-authorship network analyses. The annual number of AD publications has increased over the years. Asthma, food allergies, the skin barrier, IgE, and epidemiology have received extensive attention. The keywords 'allergic rhinitis', 'child(ren)', 'quality of life', and 'probiotics' have become more commonly used in recent years. AD research has been led by only a few countries, such as the USA, Germany, and the UK, and longstanding research topics such as asthma, allergy, and the immune system continue to be important. We suggest that global collaborations, research in developing countries, and research that is more holistic (thus exploring how genes, the immune system, the environment, and the microbiome together impact $\mathrm{AD}$ ) are necessary.
\end{abstract}

Keywords: atopic dermatitis; bibliometric analysis; asthma; immunoglobulin E; probiotics

\section{Introduction}

Atopic dermatitis $(\mathrm{AD})$ is a chronic skin disease characterized by severe pruritus, recurrent eczema, sleep disruption, and skin manifestations (erythema, edema, papulation, oozing and crusting, excoriation, lichenification, and dryness). AD primarily affects infants and young children, and the prevalence (15-20\% in children and $1-3 \%$ in adults) and recurrence rates are high [1]. AD reduces the quality of life [2], promotes suicidal ideation [3], and imposes significant economic burdens on patients and healthcare systems [4]. Patients with $\mathrm{AD}$ are hypersensitive to skin irritations, certain foods, and aero-allergens. They often develop other atopic disorders such as asthma or allergic rhinitis (the "atopic march" phenomenon [5,6]). Genetic variations, an impaired skin barrier, excessive inflammation, and allergic responses involving T-helper type 2 cytokines (e.g., interleukin [IL]-4 and IL-13), immunoglobulin E (IgE), and eosinophils have been proposed to contribute to AD pathogenesis [7]. Thus, the clinical evaluation and management of AD remain challenging [8]. Recently developed drugs (dupilumab, oluminant, and rinvoq), a growing interest in patient quality of life, and new potential therapeutic targets (such as the gut and skin microbiomes [9-14]) have motivated researchers to intensify their current approaches and explore new areas of $\mathrm{AD}$ research.

To achieve this goal, we strongly believe that bibliometric analysis is useful for tracking the rise and fall of research topics over time and for evaluating the impacts of publications, research affiliations, and journals. A bibliometric analysis provides an overview of a large number of publications, allows for the quantitative assessment of past research, and can be used to predict future research trends [15-17]). Bibliometric analysis has been used to estimate research trends in various research fields, including dermatology [17]. 
Bibliometrics can be utilized to analyze publication trends by country and institution and to identify the main keywords and organizations associated with AD research. However, to the best of our knowledge, AD research has not been analyzed using a bibliometric approach that lacks restrictions on research subjects (see Zhong et al. 2011 [18] for a bibliometric analysis of AD treated via Traditional Chinese Medicine).

We aimed to analyze publication and citation trends by year, country, journal, and organization; to assess trends in the most frequently studied topics; and to identify keyword and organization clusters by performing network analyses. We identified the most productive countries, affiliations, and journals and the 30 top-cited publications to highlight the progress made and the landmark studies. This will guide future research on AD.

\section{Methods}

\section{Data Search and Analysis}

We retrieved publications from the Web of Science and SCOPUS on 2 July 2021 using search topics including atopic dermatitis, eczema, and atopy. The retrieval strategies were TS = ("atopic dermatit" OR atopy OR "atopic eczema") for the Web of Science and TITLE-ABS-KEY ("atopic dermatit" OR "atopic eczema" OR atopy) for SCOPUS. No date range limits were applied, but we restricted our search to articles written in English. The exclusion criteria were (1) articles not retrieved from the Web of Science or SCOPUS, (2) conference and meeting abstracts, (3) corrigendum documents, and (4) retracted publications. We merged the datasets from the Web of Science and SCOPUS and removed duplicates using the mergeDbSources function of R. All articles were evaluated by ISL.

Biblioshiny (https: / / www.bibliometrix.org/Biblioshiny.html, accessed on 5 July 2021) and the 'bibliometrix' $R$ package [19] were used for the analysis of annual publication productivity (total number of publications per year), the total number of publications from each country and affiliation, the total number of citations for each article, and keyword frequency. The keyword frequency analysis was conducted for all three decades combined (1990-2020), and for each decade separately (1990-1999, 2000-2009, and 2010-2020), to identify trends in keywords over time.

We also performed a network analysis of keywords and a co-authorship-based network analysis of countries, using VOSviewer software (version 1.6.16; Centre for Science and Technology Studies, Leiden University of Leiden, Leiden, the Netherlands). Network analyses were conducted using a modularity-based clustering method. The parameters for analyses were as follows: unit of analysis = country or author keywords; fractional counting of keywords and affiliations; "layout attraction" $=3$; and clustering resolution $=0.5$. The minimum number of keyword occurrences was set to 5 , and we excluded the keywords 'atopic dermatitis', 'eczema', 'atopic eczema', and 'atopy' from analysis. Countries that published more than five articles were included in co-authorship network analysis. All nodes were weighted by occurrence and the number of documents, respectively, to aid visualization. The total link strength and normalized citation of each country were explored to determine the influence of that country on AD research.

\section{Results}

\subsection{Publication Productivity and Citations}

A total of 53,460 articles were included after removing duplicates $(n=2342)$, conference papers/abstracts $(n=44)$, meeting abstracts $(n=7094)$, corrections, and retracted publications $(n=7)$. The annual number of publications has exhibited an upward trend since 1990 (Figure 1). The 30 most-often cited articles published between 1990 and 2020 (determined by the total citations per year) are shown in Table 1 . Five studies dealt with the microbiome [20-24] and the skin barrier [25-29]; three studies explored food allergies [30-32]; and two studies were epidemiological in nature [33,34].

The 10 countries with the highest total numbers of publications were the USA, Germany, the UK, Japan, South Korea, China, France, Italy, the Netherlands, and Australia (Table 2). The total number of publications by affiliation (institution, hospital, or university) 
revealed that Northwestern University, the Karolinska Institute, the University of Copenhagen, the Technical University of Munich, Yonsei University, the University of California San Francisco, Seoul National University, Harvard University, the University of Munich, and the University of Helsinki were the most productive institutions; these are located in the USA, Sweden, Denmark, Germany, and Finland (Table 3).

The Journal of Allergy and Clinical Immunology, Allergy, Journal of Investigative and Clinical Dentistry, British Journal of Dermatology, Clinical \& Experimental Allergy, International Journal of Advanced Biotechnology and Research, Journal of the American Academy of Child and Adolescent Psychiatry, Acta Dermato-Venereologica, Pediatric Allergy and Immunology, and Contact Dermatitis were the top 10 journals in terms of AD articles published (Table 4).

\section{Annual Publications}

4000

3500

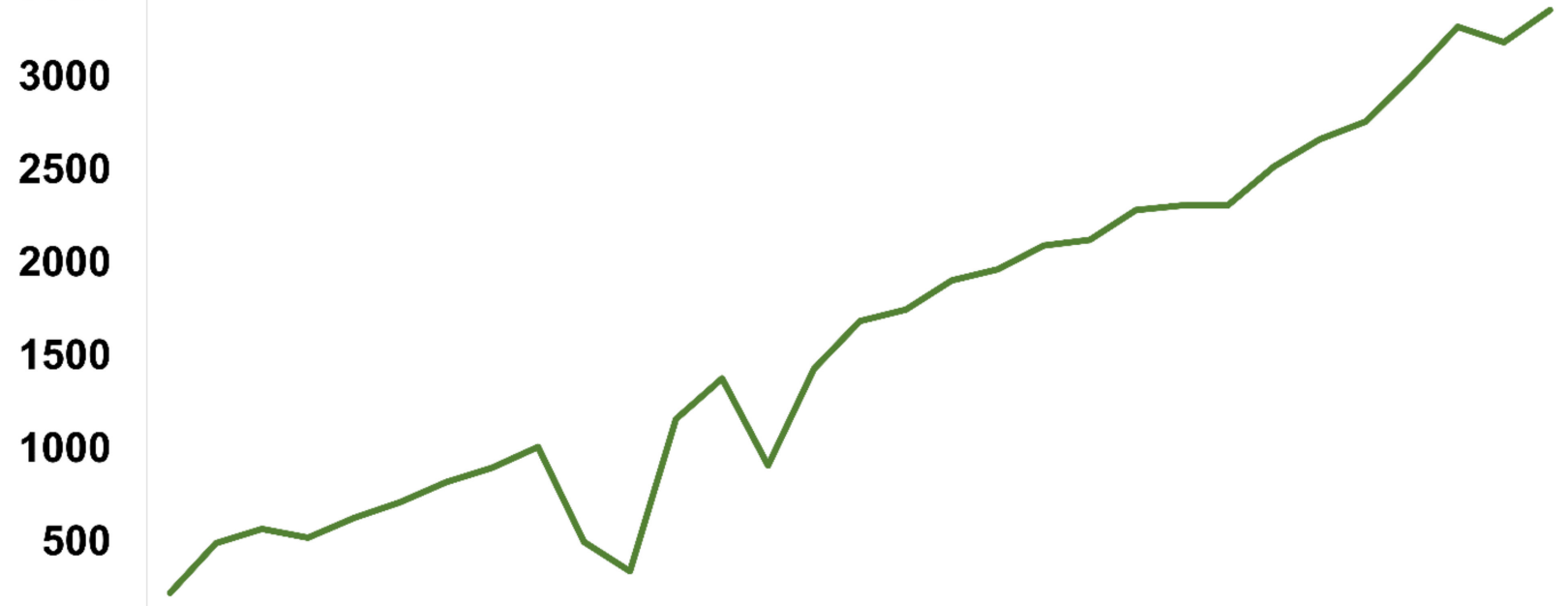

0

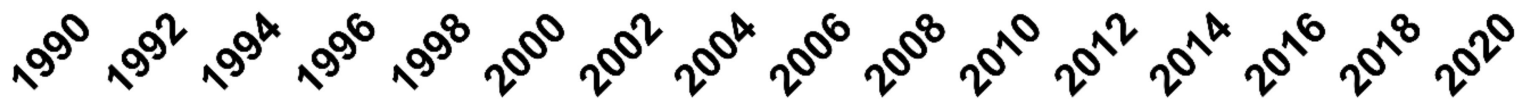

Figure 1. The total number of publications per year during the period 1990-2020.

\subsection{Keyword Frequency and Network Analyses}

Keyword frequency analysis showed that the 10 most frequently used keywords were 'asthma', 'allergy', 'child(ren)', 'IgE', '(allergic) rhinitis', 'epidemiology', 'food allergy', '(allergic) contact dermatitis', 'psoriasis', 'cytokines', and 'pruritus (itch)' (Figure 2A). We also analyzed the frequency of keywords by decade as a further analysis of the changes in research trends over the past three decades. The top five most frequently used keywords between 1990 and 1999 were 'asthma', 'IgE', '(allergic) contact dermatitis', 'epidemiology', and 'child(ren)' (Figure 2B). The top five most frequently used keywords between 2000 and 2009 were 'asthma', 'allergy', 'IgE', 'child(ren)', and 'epidemiology' (Figure 2C). The top five most frequently used keywords between 2010 and 2020 were 'asthma', 'allergy', 'child(ren)', '(allergic) rhinitis', and 'IgE' (Figure 2D). These results suggest that asthma, allergy, IgE status, and childhood AD have been extensively and consistently studied over the past three decades, although the occurrence ranking of IgE decreased over that time. The ranking of the keywords 'contact dermatitis', 'cytokines', 'IgE', 'prevention', and 'risk factor' decreased gradually, indicating that less emphasis has been placed on those research topics by AD researchers. In contrast, the keywords 'allergic rhinitis', 'child(ren)', and 'quality of life' have become more popular over the decades. The keyword 
'probiotics' entered the rankings between 2010 and 2020, revealing increasing interest in the microbiome of patients with skin disease.

Table 1. The top 30 most cited papers on atopic dermatitis over the past 30 years.

\begin{tabular}{|c|c|c|c|}
\hline No. & Articles & Total Citation/Year & Topic \\
\hline 1 & $\begin{array}{l}\text { Worldwide time trends in the prevalence of symptoms of asthma, } \\
\text { allergic rhinoconjunctivitis, and eczema in childhood: ISAAC } \\
\text { Phases One and Three repeat multicountry cross-sectional surveys }\end{array}$ & 161.56 & AD epidemiology \\
\hline 2 & $\begin{array}{c}\text { Randomized Trial of Peanut Consumption in Infants at Risk for } \\
\text { Peanut Allergy }\end{array}$ & 134.29 & Food allergy \\
\hline 3 & $\begin{array}{l}\text { Global epidemiology of psoriasis: a systematic review of incidence } \\
\text { and prevalence }\end{array}$ & 132.89 & $\begin{array}{l}\text { Other disease } \\
\text { (psoriasis) }\end{array}$ \\
\hline 4 & The skin microbiome & 118.82 & Microbiome \\
\hline 5 & $\begin{array}{c}\text { Two Phase } 3 \text { Trials of Dupilumab versus Placebo in } \\
\text { Atopic Dermatitis }\end{array}$ & 117.5 & Clinical trial \\
\hline 6 & $\begin{array}{c}\text { Unbiased classification of sensory neuron types by large-scale } \\
\text { single-cell RNA sequencing }\end{array}$ & 114.86 & Itch \\
\hline 7 & $\begin{array}{l}\text { Common loss-of-function variants of the epidermal barrier protein } \\
\text { filaggrin are a major predisposing factor for atopic dermatitis }\end{array}$ & 114.19 & Skin barrier \\
\hline 8 & $\begin{array}{l}\text { Guidelines for the diagnosis and management of food allergy in the } \\
\text { United States: report of the NIAID-sponsored expert panel }\end{array}$ & 112.33 & Food allergy \\
\hline 9 & $\begin{array}{l}\text { Worldwide variation in prevalence of symptoms of asthma, allergic } \\
\text { rhinoconjunctivitis, and atopic eczema: ISAAC }\end{array}$ & 111 & AD epidemiology \\
\hline 10 & $\begin{array}{c}\text { Dermatology Life Quality Index (DLQI)—a simple practical } \\
\text { measure for routine clinical use }\end{array}$ & 98.75 & Questionnaire \\
\hline 11 & Prebiotic effects: metabolic and health benefits & 93.67 & Microbiome \\
\hline 12 & Atopic Dermatitis & 91 & Review \\
\hline 13 & $\begin{array}{c}\text { International Study of Asthma and Allergies in Childhood (ISAAC): } \\
\text { rationale and methods }\end{array}$ & 88.70 & Study introduction \\
\hline 14 & $\begin{array}{c}\text { The effect of infections on susceptibility to autoimmune and } \\
\text { allergic diseases }\end{array}$ & 85.65 & Infection \\
\hline 15 & $\begin{array}{l}\text { Temporal shifts in the skin microbiome associated with disease } \\
\text { flares and treatment in children with atopic dermatitis }\end{array}$ & 81.2 & Microbiome \\
\hline 16 & $\begin{array}{c}\text { Exposure to Environmental Microorganisms and } \\
\text { Childhood Asthma }\end{array}$ & 81.09 & Microbiome \\
\hline 17 & $\begin{array}{c}\text { Revised nomenclature for allergy for global use: Report of the } \\
\text { Nomenclature Review Committee of the World Allergy } \\
\text { Organization, October } 2003\end{array}$ & 79.89 & Nomenclature \\
\hline 18 & $\begin{array}{c}\text { Probiotics in primary prevention of atopic disease: a randomised } \\
\text { placebo-controlled trial }\end{array}$ & 79.76 & Microbiome \\
\hline 19 & The development of allergic inflammation & 75.07 & Review \\
\hline 20 & $\begin{array}{l}\text { Human epithelial cells trigger dendritic cell-mediated allergic } \\
\text { inflammation by producing TSLP }\end{array}$ & 70.75 & Skin barrier \\
\hline 21 & $\begin{array}{l}\text { Eosinophilic esophagitis in children and adults: a systematic review } \\
\text { and consensus recommendations for diagnosis and treatment }\end{array}$ & 69.53 & $\begin{array}{l}\text { Other disease } \\
\text { (eosinophilic } \\
\text { esophagitis) }\end{array}$ \\
\hline 22 & Pathogenesis and clinical features of psoriasis & 69.07 & $\begin{array}{l}\text { Other disease } \\
\text { (psoriasis) }\end{array}$ \\
\hline 23 & $\begin{array}{l}\text { Endogenous Antimicrobial Peptides and Skin Infections in } \\
\text { Atopic Dermatitis }\end{array}$ & 66.15 & Skin barrier \\
\hline 24 & The skin: an indispensable barrier & 62.93 & Skin barrier \\
\hline 25 & $\begin{array}{l}\text { A revised nomenclature for allergy. An EAACI position statement } \\
\text { from the EAACI nomenclature task force }\end{array}$ & 58.71 & Nomenclature \\
\hline 26 & $\begin{array}{l}\text { Impaired TH17 cell differentiation in subjects with autosomal } \\
\text { dominant hyper-IgE syndrome }\end{array}$ & 58.21 & $\begin{array}{l}\text { Other disease } \\
\text { (hyper-IgE } \\
\text { syndrome) }\end{array}$ \\
\hline 27 & IL-22 increases the innate immunity of tissues & 56.56 & Interleukin \\
\hline 28 & New insights into atopic dermatitis & 55.89 & Review \\
\hline 29 & Skin immune sentinels in health and disease & 55.31 & Skin barrier \\
\hline 30 & Update on food allergy & 54.28 & Food allergy \\
\hline
\end{tabular}


Table 2. The total number of publications from the top 30 countries during the period 1990-2020.

\begin{tabular}{|c|c|c|}
\hline No. & Country & Total Publications \\
\hline 1 & USA & 31,851 \\
\hline 2 & Germany & 15,071 \\
\hline 3 & UK & 11,611 \\
\hline 4 & Japan & 11,500 \\
\hline 5 & South Korea & 9810 \\
\hline 6 & China & 8460 \\
\hline 7 & France & 7343 \\
\hline 8 & Italy & 6314 \\
\hline 9 & Netherlands & 5604 \\
\hline 10 & Australia & 5162 \\
\hline 11 & Sweden & 4859 \\
\hline 12 & Spain & 4116 \\
\hline 13 & Canada & 4071 \\
\hline 14 & Denmark & 3837 \\
\hline 15 & Finland & 3033 \\
\hline 16 & Switzerland & 2815 \\
\hline 17 & Turkey & 2651 \\
\hline 18 & Poland & 2414 \\
\hline 19 & Brazil & 2031 \\
\hline 20 & Austria & 1468 \\
\hline 21 & Iran & 1424 \\
\hline 22 & India & 1374 \\
\hline 23 & Norway & 1280 \\
\hline 24 & Belgium & 1271 \\
\hline 25 & Singapore & 1130 \\
\hline 26 & Israel & 1084 \\
\hline 27 & Ireland & 955 \\
\hline 28 & New Zealand & 952 \\
\hline 29 & Greece & 764 \\
\hline 30 & Portugal & 757 \\
\hline
\end{tabular}

Of the 1800 keywords extracted from the titles and abstracts of the studies, 96 (excluding "atopic dermatitis", "eczema", "atopic eczema", and "atopy") were included in the network analysis. Five clusters were defined based on the co-occurrences of each keyword and other keywords (Figure 3 and Table 5). Cluster 1 included 42 keywords associated with asthma, allergies, and the microbiome (e.g., 'asthma', 'allergies', 'children', 'IgE', 'microbiota', 'probiotics', and 'allergic rhinitis'). Of the keywords in Cluster 1, 'vitamin $\mathrm{D}^{\prime}$ ' and 'microbiota' were relatively new (thus more commonly employed in recent years) (pink cluster in Figure 3). Cluster 2 comprised 26 keywords associated with the skin barrier and epidemiology (e.g., 'filaggrin', 'prevalence', 'risk factors', 'atopic march', and 'quality of life'; orange cluster in Figure 3). Of the keywords in Cluster 2, 'meta-analysis', 'systematic review', 'phenotype', and 'pediatrics' were relatively new. Cluster 3 included 14 keywords associated with allergens and skin tests (e.g., 'patch test', 'food allergens', and 'aeroallergens'; green cluster in Figure 3). Cluster 4 included 11 keywords associated with skin contact (e.g., 'contact dermatitis', 'contact allergy', 'patch test', 'occupational', and 'wet work'; blue cluster in Figure 3). Cluster 5 included keywords associated with non-skin diseases ('hay fever', 'obesity', and 'rhinoconjunctivitis'; red cluster in Figure 3).

\subsection{Co-Authorship Network Analysis}

Of the 103 countries, 38 were included in the co-authorship analysis, and four clusters were identified (Figure 4 and Table 6). Cluster 1 included 18 countries, almost all of which are European (e.g., Germany, the UK, Italy, France, and the Netherlands; red cluster in Figure 4). Co-authorship connections were also found between European countries and Singapore, Austria, or New Zealand (Cluster 1). Cluster 2 contained 12 countries in the Americas (including the USA, Brazil, and Mexico), Canada, and East Asia (Japan, China, 
Hong Kong, and South Korea; green cluster in Figure 4). Cluster 3 included Turkey, Greece, and India (blue cluster in Figure 4). Cluster 4 included Switzerland and the Czech Republic (yellow cluster in Figure 4). Cluster 5 included Australia and Thailand (purple cluster in Figure 4).

Germany, the USA, the UK, Sweden, and the Netherlands exhibited the greatest normalized citation scores $(326,311,249,151$, and 144, respectively) and total link strengths (in a slightly different order), suggesting that these countries exert the most influence on $\mathrm{AD}$ research in terms of both impactful papers and global collaborations that have been in operation for decades.

Table 3. The total number of publications from the top 30 affiliations during the period 1990-2020.

\begin{tabular}{|c|c|c|}
\hline No. & Affiliation (Country) & Total Publications \\
\hline 1 & Northwestern Univ. (USA) & 1371 \\
\hline 2 & Karolinska Inst. (Sweden) & 1285 \\
\hline 3 & Univ. Copenhagen (Denmark) & 1026 \\
\hline 4 & Tech. Univ. Munich (Germany) & 819 \\
\hline 5 & Yonsei Univ. (South Korea) & 776 \\
\hline 6 & Univ. California San Francisco (USA) & 772 \\
\hline 7 & Seoul Natl. Univ. (South Korea) & 756 \\
\hline 8 & Harvard Univ. (USA) & 724 \\
\hline 9 & Univ. Munich (Germany) & 710 \\
\hline 10 & Univ. Helsinki (Finland) & 675 \\
\hline 11 & Johns Hopkins Univ. (USA) & 630 \\
\hline 12 & Univ. Pennsylvania (USA) & 627 \\
\hline 13 & Icahn Sch. of Med. at Mountain Sinai (USA) & 624 \\
\hline 14 & Univ. Southampton (UK) & 588 \\
\hline 15 & Univ. Groningen (Netherlands) & 585 \\
\hline 16 & King's college London (UK) & 582 \\
\hline 17 & Univ. California San Diego (USA) & 580 \\
\hline 18 & Hannover Med. Sch. (Germany) & 568 \\
\hline 19 & Kyung Hee Uni. (South Korea) & 568 \\
\hline 20 & Chinese Univ. Hong Kong (Hong Kong) & 567 \\
\hline 21 & Univ. Melbourne (Australia) & 566 \\
\hline 22 & $\begin{array}{l}\text { Univ. Western Australia } \\
\text { (Australia) }\end{array}$ & 551 \\
\hline 23 & $\begin{array}{l}\text { Univ. Amsterdam } \\
\text { (Netherlands) }\end{array}$ & 546 \\
\hline 24 & Oregon Health and Science Univ. (USA) & 535 \\
\hline 25 & Univ. Nottingham (UK) & 505 \\
\hline 26 & Univ. Colorado (USA) & 495 \\
\hline 27 & Univ. Toronto (Canada) & 482 \\
\hline 28 & Univ. Manchester (UK) & 473 \\
\hline 29 & Univ. Med. Center Utrecht (Netherlands) & 440 \\
\hline 30 & Univ. Utrecht (Netherlands) & 437 \\
\hline
\end{tabular}

Table 4. The top 30 journals in terms of atopic dermatitis publications over the past 30 years.

\begin{tabular}{|c|c|c|c|c|c|}
\hline No. & Journal & Total Publications & No. & Journal & Total Publications \\
\hline 1 & $\begin{array}{l}\text { Journal of Allergy and } \\
\text { Clinical Immunology }\end{array}$ & 3269 & 16 & $\begin{array}{l}\text { Current Opinion in Allergy and } \\
\text { Clinical Immunology }\end{array}$ & 469 \\
\hline 2 & Allergy & 2528 & 17 & Revue Française d'Allergologie & 466 \\
\hline 3 & $\begin{array}{c}\text { Journal of Investigative and } \\
\text { Clinical Dentistry }\end{array}$ & 2395 & 18 & $\begin{array}{l}\text { Archives of } \\
\text { Dermatological Research }\end{array}$ & 462 \\
\hline 4 & British Journal of Dermatology & 2105 & 19 & Der Hautarzt & 429 \\
\hline 5 & $\begin{array}{l}\text { Clinical \& Experimental Allergy } \\
\text { International Journal of }\end{array}$ & 1878 & 20 & PLOS One & 425 \\
\hline 6 & $\begin{array}{c}\text { Advanced Biotechnology } \\
\text { and Research }\end{array}$ & 1314 & 21 & Veterinary Dermatology & 418 \\
\hline
\end{tabular}


Table 4. Cont.

\begin{tabular}{|c|c|c|c|c|c|}
\hline No. & Journal & Total Publications & No. & Journal & Total Publications \\
\hline & Journal of the American & & & & \\
\hline 7 & $\begin{array}{l}\text { Academy of Child and } \\
\text { Adolescent Psychiatry }\end{array}$ & 1182 & 22 & Pediatric Dermatology & 415 \\
\hline 8 & Acta Dermato-Venereologica & 1046 & 23 & Allergologie & 400 \\
\hline 9 & $\begin{array}{l}\text { Pediatric Allergy } \\
\text { and Immunology }\end{array}$ & 999 & 24 & $\begin{array}{l}\text { American Journal of Respiratory } \\
\text { and Critical Care Medicine }\end{array}$ & 399 \\
\hline 10 & Contact Dermatitis & 969 & 25 & The Journal of Dermatology & 393 \\
\hline 11 & $\begin{array}{l}\text { Annals of Allergy, Asthma } \\
\text { and Immunology }\end{array}$ & 772 & 26 & European Respiratory Journal & 355 \\
\hline 12 & $\begin{array}{l}\text { International Archives of } \\
\text { Allergy and Immunology }\end{array}$ & 686 & 27 & $\begin{array}{l}\text { Journal der Deutschen } \\
\text { Dermatologischen Gesellschaft }\end{array}$ & 339 \\
\hline & Journal of the European & & & & \\
\hline 13 & $\begin{array}{l}\text { Academy of Dermatology } \\
\text { and Venereology }\end{array}$ & 673 & 28 & Dermatology & 324 \\
\hline 14 & $\begin{array}{c}\text { Journal of Dermatological } \\
\text { Case Reports }\end{array}$ & 660 & 29 & $\begin{array}{c}\text { Annales de Dermatologie et } \\
\text { de Vénéréologie }\end{array}$ & 319 \\
\hline 15 & Experimental Dermatology & 655 & 30 & Journal of Immunology & 314 \\
\hline
\end{tabular}

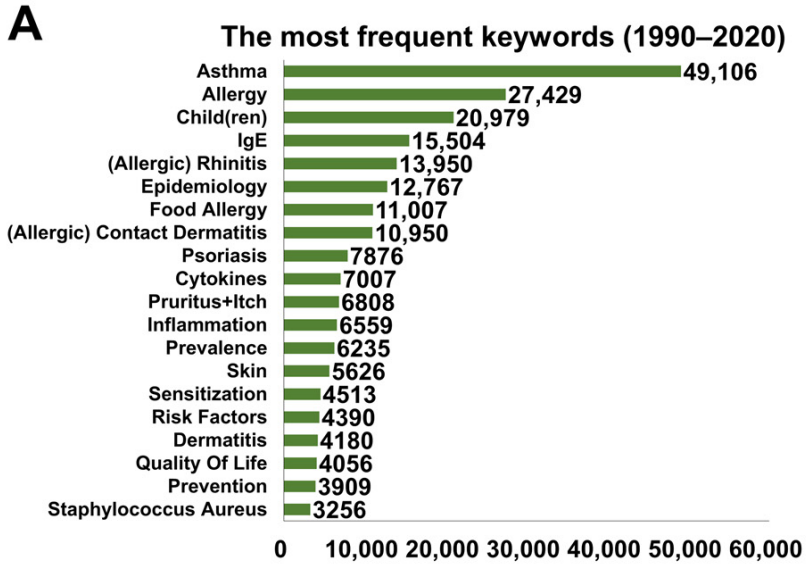

C

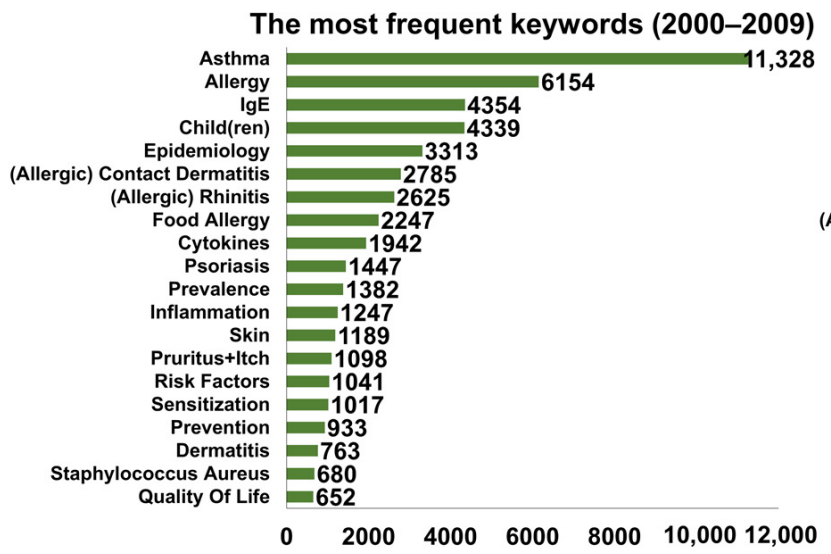

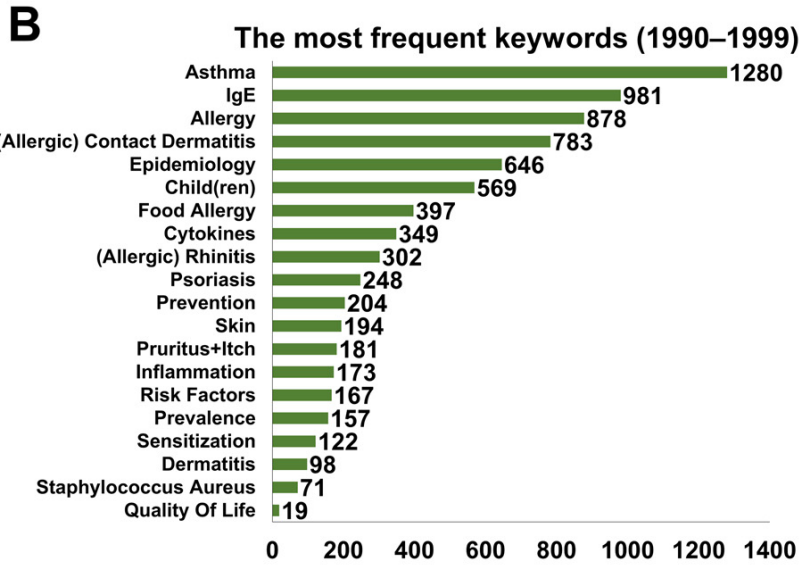

D

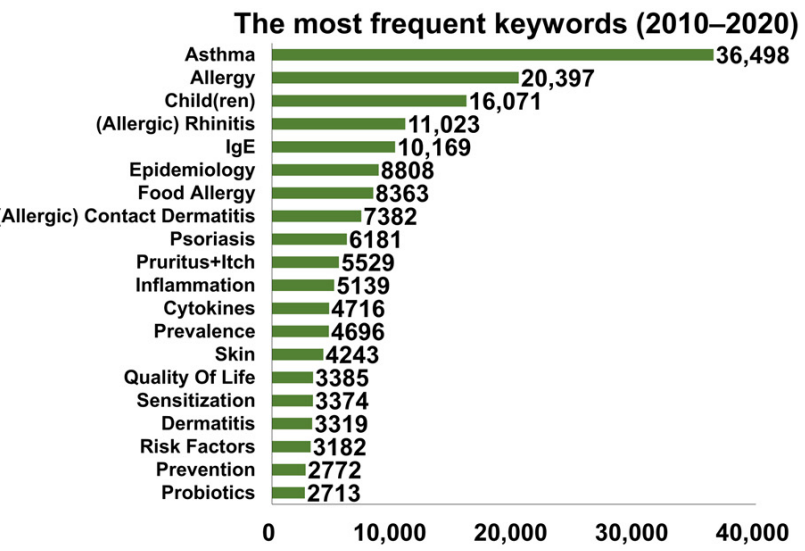

Figure 2. The most frequently used keywords ordered by occurrence in the period 1990-2020. (A) Number of the most frequently used keywords from 1990 to 2020 from publications in AD research. During the past three decades, 'Asthma', 'Allergy', 'Child(ren)', 'IgE', and '(Allergic) Rhinitis' have been the most commonly used keywords; (B) Number of the most frequently used keywords from 1990 to 1999. During the early years of AD research, the top five most frequently used keywords were 'Asthma', 'IgE', '(Allergic) Contact Dermatitis', 'Epidemiology', and 'Child(ren)'; (C) Number of the most frequently used keywords from 2020 to 2009. The keyword 'Child(ren)' had become more popular than the previous decade; (D) Number of the most frequently used keywords from 2010 to 2020. 


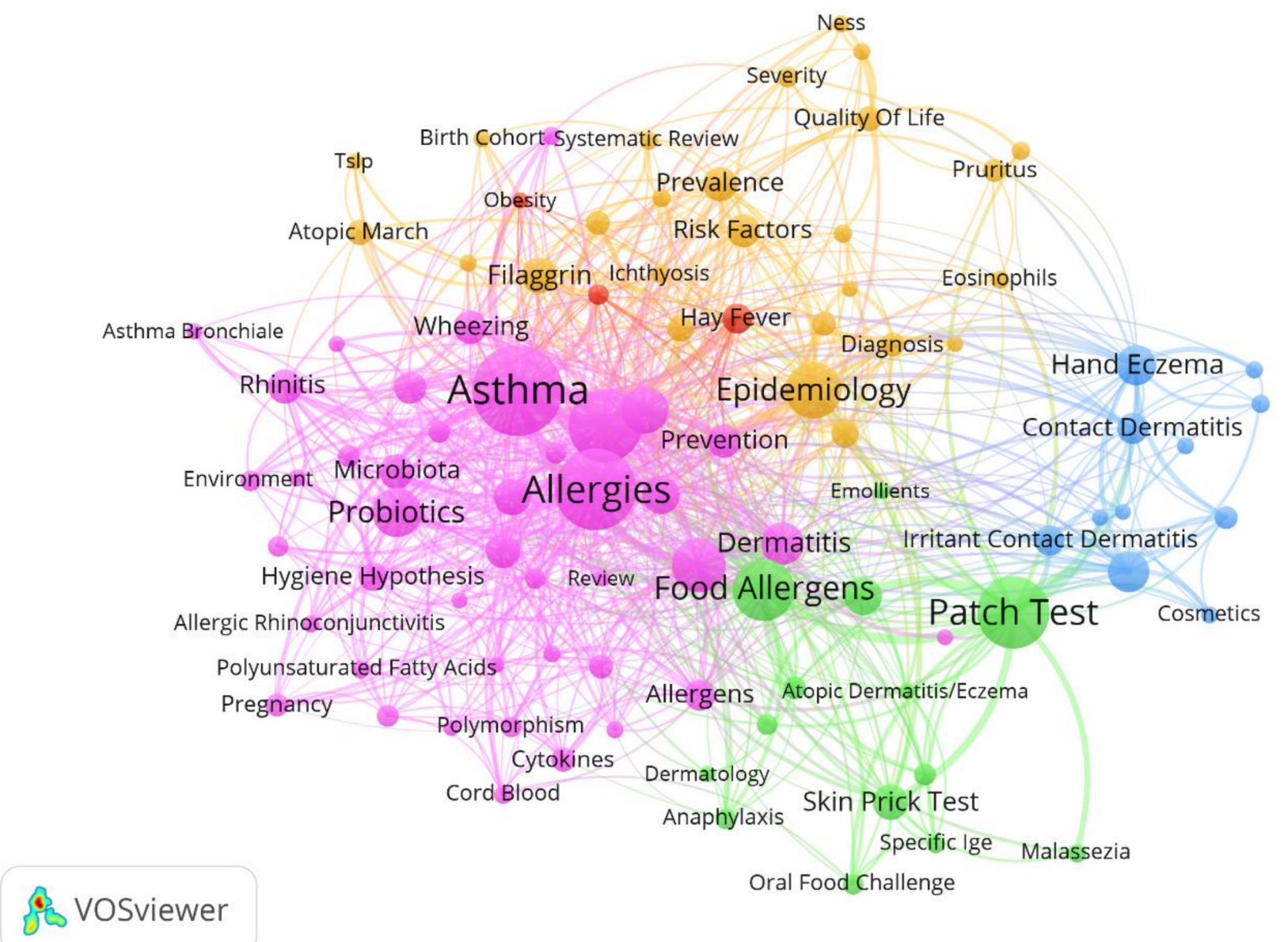

Figure 3. Network analysis of author keywords during the period 1990-2020. Keywords used more than five times were included in the network analysis; the keywords 'atopic dermatitis', 'eczema', 'atopic eczema', and 'atopy' were excluded. The following parameters for VOSviewer were used: layout attraction of 3 , clustering resolution of 0.5 , visualization scale of 1.3 , and size variation of 0.6 ; node sizes were weighted based on the keyword frequencies in the clusters.

Table 5. Top 10 keywords in each cluster based on keyword network analysis (sorted by total link strength).

\begin{tabular}{ccccc}
\hline Cluster & Keywords & Total Link Strength & Occurrences & Average Publication Year \\
\hline & Asthma & 142 & 154 & 2010 \\
Allergies & 114 & 124 & 2010 \\
Children & IgE & 91 & 100 & 2009 \\
& Probiotics & 47 & 44 & 2008 \\
& Allergic Rhinitis & 40 & 42 & 2010 \\
& Dermatitis & 39 & 34 & 2012 \\
& Sensitization & 29 & 27 & 2009 \\
& Rhinitis & 26 & 23 & 2011 \\
& Allergic Diseases & 22 & 25 & 2010 \\
\hline & Epidemiology & 22 & 60 & 2006 \\
Filaggrin & 51 & 24 & 2012 \\
& Prevalence & 22 & 23 & 2009 \\
& Risk Factors & 19 & 21 & 2009 \\
Skin Barrier & 17 & 13 & 2011 \\
& Treatment & 13 & 15 & 2010 \\
& Meta-Analysis & 13 & 11 & 2015 \\
& Quality of Life & 11 & 12 & 2013 \\
& Diagnosis & 11 & 11 & 2005 \\
& Severity & 11 & 8 & 2011 \\
\hline
\end{tabular}


Table 5. Cont

\begin{tabular}{|c|c|c|c|c|}
\hline Cluster & Keywords & Total Link Strength & Occurrences & Average Publication Year \\
\hline \multirow{10}{*}{ Cluster 3} & Patch Test & 75 & 97 & 2006 \\
\hline & Food Allergens & 66 & 73 & 2010 \\
\hline & Aeroallergens & 26 & 27 & 2006 \\
\hline & Skin Prick Test & 22 & 24 & 2006 \\
\hline & Urticaria & 8 & 10 & 2006 \\
\hline & Oral Food Challenge & 8 & 8 & 2009 \\
\hline & Cow's Milk Allergy & 7 & 9 & 2007 \\
\hline & Anaphylaxis & 7 & 8 & 2009 \\
\hline & Food & 7 & 8 & 2009 \\
\hline & Malassezia & 6 & 7 & 2005 \\
\hline \multirow{10}{*}{ Cluster 4} & Allergic Contact Dermatitis & 28 & 32 & 2010 \\
\hline & Contact Allergy & 4 & 7 & 2007 \\
\hline & Contact Dermatitis & 14 & 18 & 2012 \\
\hline & Contact Urticaria & 2 & 6 & 2000 \\
\hline & Cosmetics & 6 & 6 & 2017 \\
\hline & Hand Eczema & 27 & 31 & 2005 \\
\hline & Immunology & 3 & 5 & 2007 \\
\hline & Irritant Contact Dermatitis & 17 & 17 & 2011 \\
\hline & Occupational & 10 & 10 & 2002 \\
\hline & Therapy & 3 & 5 & 2008 \\
\hline \multirow{3}{*}{ Cluster 5} & Hay Fever & 17 & 17 & 2007 \\
\hline & Obesity & 4 & 5 & 2013 \\
\hline & Rhinoconjunctivitis & 8 & 8 & 2011 \\
\hline
\end{tabular}

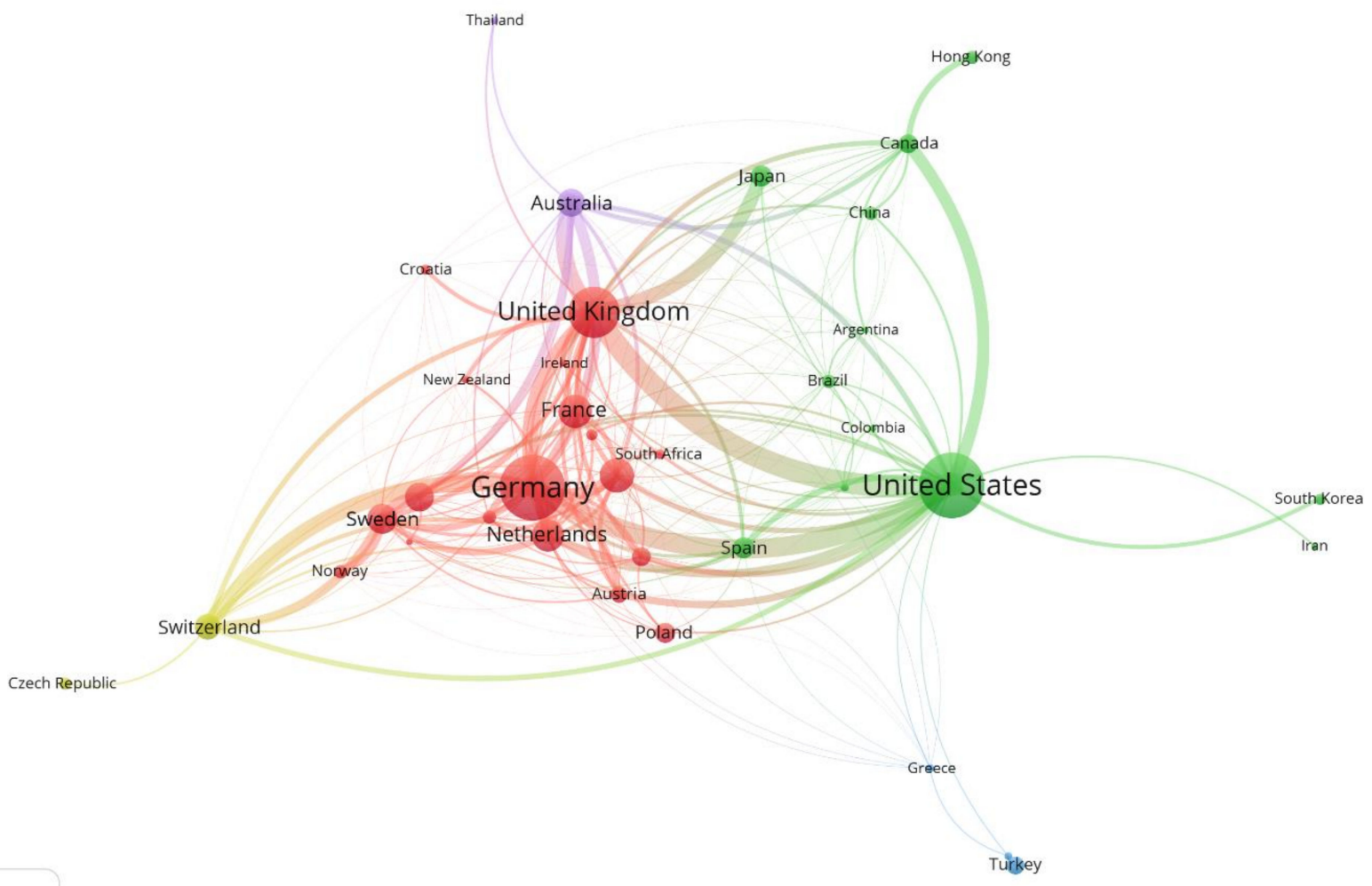

vosviewer

Figure 4. Co-authorship networks of countries during the period 1990-2020. Organizations that published more than five articles were included in the co-authorship network analysis. The following parameters for VOSviewer were used: layout attraction of 3 , clustering resolution of 0.5 , visualization scale of 1.3 , and size variation of 0.6 ; the node sizes were weighted based on the number of documents. Five clusters were identified. The USA, the UK, and Germany were central hubs of collaborative research. 
Table 6. Top 10 countries in each cluster based on co-authorship network analysis during the period 1990-2020 (sorted by total link strength).

\begin{tabular}{|c|c|c|c|}
\hline Cluster & Countries & Total Link Strength & Normalized Citation \\
\hline \multirow{10}{*}{ Cluster 1} & United Kingdom & 68 & 248.76 \\
\hline & Germany & 65 & 326.07 \\
\hline & Netherlands & 34 & 143.96 \\
\hline & Sweden & 33 & 150.96 \\
\hline & Italy & 28 & 110.06 \\
\hline & Austria & 16 & 31.75 \\
\hline & Finland & 15 & 141.94 \\
\hline & France & 14 & 73.85 \\
\hline & Denmark & 14 & 98.86 \\
\hline & Belgium & 12 & 54.05 \\
\hline \multirow{10}{*}{ Cluster 2} & United States & 64 & 311.38 \\
\hline & Canada & 19 & 46.66 \\
\hline & Spain & 13 & 41.09 \\
\hline & Japan & 10 & 48.08 \\
\hline & Brazil & 7 & 19.07 \\
\hline & Mexico & 6 & 33.99 \\
\hline & China & 5 & 17.47 \\
\hline & Argentina & 5 & 8.10 \\
\hline & Colombia & 3 & 5.07 \\
\hline & Hong Kong & 3 & 12.95 \\
\hline \multirow{3}{*}{ Cluster 3} & Greece & 3 & 15.51 \\
\hline & India & 2 & 2.27 \\
\hline & Turkey & 1 & 12.69 \\
\hline \multirow{2}{*}{ Cluster 4} & Switzerland & 25 & 85.53 \\
\hline & Czech Republic & 1 & 2.92 \\
\hline \multirow{2}{*}{ Cluster 5} & Australia & 30 & 114.33 \\
\hline & Thailand & 2 & 2.62 \\
\hline
\end{tabular}

\section{Discussion}

Analysis of the 53,460 articles collected from the Web of Science and SCOPUS databases showed that the number of publications on AD has increased since 1990. The citation and keyword frequency analyses revealed that research topics such as asthma, food allergies, the skin barrier, IgE, and epidemiology have received extensive attention. The rankings of the keywords 'contact dermatitis', 'cytokines', 'IgE', 'prevention', and 'risk factor' decreased gradually over time, while the keywords 'allergic rhinitis', 'child(ren)', 'quality of life', and 'probiotics' have become more popular. We identified five main AD-related topics (inflammation and allergy, the skin barrier, allergens, contact dermatitis, and non-skin diseases). The USA, Germany, the UK, Japan, and South Korea were the top five most productive countries in the field of AD research. The USA, Germany, the UK, Sweden, and the Netherlands exerted the greatest influence on AD research.

The most cited article (published in 2006) addressed the prevalence of eczema in childhood [33]. That study conducted a cross-sectional questionnaire survey in 193,404 children from 37 countries (aged 6-7 years) and 304,679 children from 56 countries (aged 13-14 years). The top citation rate suggests that researchers are very interested in the different prevalences of eczema worldwide; geographical variation may be important in terms of the development of asthma and allergies. The cited authors found that the prevalences of eczema symptoms in both groups increased over time in most regions but decreased in some. An understanding of the factors promoting the decreases might allow the effective prevention and treatment of allergic diseases. The fourth most-cited article dealt with the skin microbiome [20], suggesting that microbial factors may contribute to AD development. Indeed, recent studies have suggested that an impaired skin microbiome can affect both the 
skin barrier [12] and the immune environment [14], eventually causing AD development and worsening the symptoms [13].

\subsection{Sustainable and Newly Highlighted Research Themes}

$\mathrm{AD}$ is frequently associated with respiratory allergic diseases, such as asthma and allergic rhinitis. The term "atopic march", which refers to the progression of symptoms from $\mathrm{AD}$ to asthma to allergic rhinitis during childhood, emphasizes the strong association between $\mathrm{AD}$ and respiratory allergy. While the preventative effects of treating atopic march are controversial, IgE-associated allergic reactions are regarded as a key mechanism of AD, and our keyword frequency analysis emphasized the significance of the keywords 'asthma', 'allergy', and 'IgE' (the ranking of the latter decreased over time, but it still remains in the most recent top five). As $\mathrm{AD}$ is a chronic and recurrent disease, managing quality of life has become a major concern when treating $\mathrm{AD}$ patients. In contrast, the keywords 'contact dermatitis' and 'cytokine' dropped in the rankings, which might reflect the reduced interest of $\mathrm{AD}$ researchers in contact dermatitis. However, as AD patients may have an increased risk of contact sensitization, and contact dermatitis is more severe in patients with than without AD [35,36], studies that focus on the weak, sensitized skin of AD patients remain meritorious. We performed citation and keyword frequency analyses to identify topics that have recently received significant attention. These topics included the microbiome and probiotics. The roles played by the microbiological environments of the skin and other organs (e.g., the gut) remain poorly understood, as do the effects of probiotics [9]. As patients are now increasingly exposed to commercial probiotics, any abnormal changes in the composition or functions of the $\mathrm{AD}$ microbiome require attention, as do any effect of probiotics on AD. Such work might yield new treatments for AD.

\subsection{Insufficient Global Collaborative Research Network}

The co-authorship network analysis identified five clusters of countries. The UK, Germany, the USA, the Netherlands, and Sweden were influential research hubs; these countries scored highest in terms of total link strength. On the other hand, Japan and South Korea were both very productive, but the citation scores were rather low, suggesting that research quality requires improvement. The clusters consisted mainly of neighboring countries or those on the same continent, indicating that there are only a few intercontinental global collaborations in AD research. Building an international network to strengthen the research community, and enhance research quality and diversity, could be valuable.

\subsection{Future Directions}

It is important to note that although $\mathrm{AD}$ is a worldwide disease, research thereon has mostly been performed in a few developed countries and may not be transferable to $\mathrm{AD}$ patients in developing countries. Thus, AD patients in developing countries might not benefit from the research findings, even though studies have shown an increasing prevalence of $\mathrm{AD}$ in such countries [33,37]. For example, the mechanisms and risk factors in developing countries could be different to those in developed countries. Therefore, it is necessary to train healthcare providers and improve patient access to healthcare resources, as well as to facilitate $\mathrm{AD}$ research, in developing countries.

In addition to skin barrier impairments in the context of food and skin contact, $\mathrm{AD}$ is also related to environmental factors (e.g., climate, UV light exposure, temperature, and air pollution), diet, and the gut and skin microbiomes [38]. We suggest that collaborations among epidemiologists, basic scientists, clinical researchers, microbiologists, and pharmaceutical industrialists, and the establishment of international research networks, will improve our knowledge of the causes of $\mathrm{AD}$ and enable us to treat $\mathrm{AD}$ more effectively in the future. 


\subsection{Limitations}

This study had several limitations. The quality of the publications was not considered, and all authors were treated equally regardless of their contribution to the work (e.g., first, corresponding, or co-author). Finally, some institutes might have close relationships (e.g., the Karolinska Institute and Karolinska University Hospital), although we changed or combined organization names to account for this.

\section{Conclusions}

In conclusion, the countries leading $\mathrm{AD}$ research have been the USA, Germany, the UK, Japan, South Korea, Sweden, and the Netherlands. The most prevalent research themes have been 'asthma', 'allergy', 'child(ren)', 'IgE', '(allergic) rhinitis', 'epidemiology', 'food allergy', '(allergic) contact dermatitis', 'psoriasis', 'cytokines', and 'pruritus (itch)'. Five research topic clusters were identified (inflammation and allergy, skin barrier, allergens, contact dermatitis, and non-skin diseases). Our analyses identified global temporal trends and the current status of AD research and suggest possible future research hotspots. For example, the lack of international research networks and interdisciplinary studies, and the few publications from developing countries, are limitations of AD research. We suggest that global collaborations, research in developing countries, and research on multiple factors (genes, the immune system, the environment, and the microbiome) are required in the field of AD research.

Author Contributions: D.K. and I.-S.L. carried out the data extraction and bibliometric analysis, prepared the first draft. Y.C. and H.-J.P. interpreted the data, and ISL finalized the manuscript. Y.C., H.-J.P. and I.-S.L. performed the critical revision of the manuscript for important intellectual content. All authors have read and agreed to the published version of the manuscript.

Funding: This work was supported by the National Research Foundation of Korea and funded by the Korean government (NRF-2020R1A4A1018598, 2021R1F1A1050116) and a grant from Kyung Hee University in 2020 (KHU-20201228).

Data Availability Statement: All data are available upon request to the corresponding author.

Conflicts of Interest: The authors declare no conflict of interest.

\section{References}

1. Nutten, S. Atopic dermatitis: Global epidemiology and risk factors. Ann. Nutr. Metab. 2015, 66 (Suppl. S1), 8-16. [CrossRef] [PubMed]

2. Blome, C.; Radtke, M.A.; Eissing, L.; Augustin, M. Quality of Life in Patients with Atopic Dermatitis: Disease Burden, Measurement, and Treatment Benefit. Am. J. Clin. Dermatol. 2016, 17, 163-169. [CrossRef] [PubMed]

3. Pompili, M.; Bonanni, L.; Gualtieri, F.; Trovini, G.; Persechino, S.; Baldessarini, R.J. Suicidal risks with psoriasis and atopic dermatitis: Systematic review and meta-analysis. J. Psychosom. Res. 2021, 141, 110347. [CrossRef] [PubMed]

4. Chung, J.; Simpson, E.L. The socioeconomics of atopic dermatitis. Ann. Allergy Asthma Immunol. 2019, 122, 360-366. [CrossRef]

5. Bantz, S.K.; Zhu, Z.; Zheng, T. The Atopic March: Progression from Atopic Dermatitis to Allergic Rhinitis and Asthma. J. Clin. Cell. Immunol. 2014, 5, 202. [CrossRef]

6. Hill, D.A.; Spergel, J.M. The atopic march: Critical evidence and clinical relevance. Ann. Allergy Asthma Immunol. 2018, 120, 131-137. [CrossRef]

7. Fiset, P.O.; Leung, D.Y.; Hamid, Q. Immunopathology of atopic dermatitis. J. Allergy Clin. Immunol. 2006, 118, 287-290. [CrossRef]

8. Lio, P.A.; Lee, M.; LeBovidge, J.; Timmons, K.G.; Schneider, L. Clinical management of atopic dermatitis: Practical highlights and updates from the atopic dermatitis practice parameter 2012. J. Allergy Clin. Immunol. Pract. 2014, 2, 361-369. [CrossRef]

9. Fang, Z.; Li, L.; Zhang, H.; Zhao, J.; Lu, W.; Chen, W. Gut Microbiota, Probiotics, and Their Interactions in Prevention and Treatment of Atopic Dermatitis: A Review. Front. Immunol. 2021, 12, 720393. [CrossRef]

10. Lee, S.Y.; Lee, E.; Park, Y.M.; Hong, S.J. Microbiome in the Gut-Skin Axis in Atopic Dermatitis. Allergy Asthma Immunol. Res. 2018, 10, 354-362. [CrossRef]

11. Salem, I.; Ramser, A.; Isham, N.; Ghannoum, M.A. The Gut Microbiome as a Major Regulator of the Gut-Skin Axis. Front. Microbiol. 2018, 9, 1459. [CrossRef]

12. Grice, E.A.; Kong, H.H.; Conlan, S.; Deming, C.B.; Davis, J.; Young, A.C.; Program, N.C.S.; Bouffard, G.G.; Blakesley, R.W.; Murray, P.R.; et al. Topographical and temporal diversity of the human skin microbiome. Science 2009, 324, 1190-1192. [CrossRef] 
13. Kennedy, E.A.; Connolly, J.; Hourihane, J.O.; Fallon, P.G.; McLean, W.H.I.; Murray, D.; Jo, J.H.; Segre, J.A.; Kong, H.H.; Irvine, A.D. Skin microbiome before development of atopic dermatitis: Early colonization with commensal staphylococci at 2 months is associated with a lower risk of atopic dermatitis at 1 year. J. Allergy Clin. Immunol. 2017, 139, 166-172. [CrossRef]

14. Nakatsuji, T.; Chen, T.H.; Narala, S.; Chun, K.A.; Two, A.M.; Yun, T.; Shafiq, F.; Kotol, P.F.; Bouslimani, A.; Melnik, A.V.; et al. Antimicrobials from human skin commensal bacteria protect against Staphylococcus aureus and are deficient in atopic dermatitis. Sci. Transl. Med. 2017, 9, 378. [CrossRef]

15. Lee, I.S.; Lee, H.; Chen, Y.H.; Chae, Y. Bibliometric Analysis of Research Assessing the Use of Acupuncture for Pain Treatment Over the Past 20 Years. J. Pain Res. 2020, 13, 367-376. [CrossRef]

16. Park, H.; Lee, I.S.; Lee, H.; Chae, Y. Bibliometric Analysis of Moxibustion Research Trends over the Past 20 Years. J. Clin. Med. 2020, 9, 1254. [CrossRef]

17. Gantenbein, L.; Arora, P.; Navarini, A.; Brandt, O.; Mueller, S.M. Global publication productivity in dermatology: A bibliometric description of the past and estimation of the future. J. Eur. Acad. Dermatol. Venereol. 2021, 35, 1424-1433. [CrossRef]

18. Zhong, Q.; Luo, H.Y.; Chang, Y.Q. A Bibliometrics Analysis of Atopic Dermatitis by Traditional Chinese Medicine. J. Hubei Univ. Natl. 2011. Available online: https:/ / en.cnki.com.cn/Article_en/CJFDTotal-FBMZ201102015.htm (accessed on 20 November 2021).

19. Aria, M.; Cuccurullo, C. bibliometrix: An R-tool for comprehensive science mapping analysis. J. Informetr. 2017, 11, 959-975. [CrossRef]

20. Grice, E.A.; Segre, J.A. The skin microbiome. Nat. Rev. Microbiol. 2011, 9, 244-253. [CrossRef]

21. Roberfroid, M.; Gibson, G.R.; Hoyles, L.; McCartney, A.L.; Rastall, R.; Rowland, I.; Wolvers, D.; Watzl, B.; Szajewska, H.; Stahl, B.; et al. Prebiotic effects: Metabolic and health benefits. Br. J. Nutr. 2010, 104 (Suppl. S2), S1-S63. [CrossRef]

22. Kong, H.H.; Oh, J.; Deming, C.; Conlan, S.; Grice, E.A.; Beatson, M.A.; Nomicos, E.; Polley, E.C.; Komarow, H.D.; NISC Comparative Sequence Program; et al. Temporal shifts in the skin microbiome associated with disease flares and treatment in children with atopic dermatitis. Genome Res. 2012, 22, 850-859. [CrossRef]

23. Ege, M.J.; Mayer, M.; Normand, A.C.; Genuneit, J.; Cookson, W.O.; Braun-Fahrlander, C.; Heederik, D.; Piarroux, R.; von Mutius, E.; The GABRIELA Transregio 22 Study Group. Exposure to environmental microorganisms and childhood asthma. N. Engl. J. Med. 2011, 364, 701-709. [CrossRef]

24. Kalliomaki, M.; Salminen, S.; Arvilommi, H.; Kero, P.; Koskinen, P.; Isolauri, E. Probiotics in primary prevention of atopic disease: A randomised placebo-controlled trial. Lancet 2001, 357, 1076-1079. [CrossRef]

25. Palmer, C.N.; Irvine, A.D.; Terron-Kwiatkowski, A.; Zhao, Y.; Liao, H.; Lee, S.P.; Goudie, D.R.; Sandilands, A.; Campbell, L.E.; Smith, F.J.; et al. Common loss-of-function variants of the epidermal barrier protein filaggrin are a major predisposing factor for atopic dermatitis. Nat. Genet. 2006, 38, 441-446. [CrossRef]

26. Soumelis, V.; Reche, P.A.; Kanzler, H.; Yuan, W.; Edward, G.; Homey, B.; Gilliet, M.; Ho, S.; Antonenko, S.; Lauerma, A.; et al. Human epithelial cells trigger dendritic cell mediated allergic inflammation by producing TSLP. Nat. Immunol. 2002, 3, 673-680. [CrossRef]

27. Ong, P.Y.; Ohtake, T.; Brandt, C.; Strickland, I.; Boguniewicz, M.; Ganz, T.; Gallo, R.L.; Leung, D.Y. Endogenous antimicrobial peptides and skin infections in atopic dermatitis. N. Engl. J. Med. 2002, 347, 1151-1160. [CrossRef]

28. Proksch, E.; Brandner, J.M.; Jensen, J.M. The skin: An indispensable barrier. Exp. Dermatol. 2008, 17, 1063-1072. [CrossRef]

29. Nestle, F.O.; Di Meglio, P.; Qin, J.Z.; Nickoloff, B.J. Skin immune sentinels in health and disease. Nat. Rev. Immunol. 2009, 9, 679-691. [CrossRef]

30. Du Toit, G.; Roberts, G.; Sayre, P.H.; Bahnson, H.T.; Radulovic, S.; Santos, A.F.; Brough, H.A.; Phippard, D.; Basting, M.; Feeney, M.; et al. Randomized trial of peanut consumption in infants at risk for peanut allergy. N. Engl. J. Med. 2015, 372, 803-813. [CrossRef]

31. Panel, N.I.-S.E.; Boyce, J.A.; Assa'ad, A.; Burks, A.W.; Jones, S.M.; Sampson, H.A.; Wood, R.A.; Plaut, M.; Cooper, S.F.; Fenton, M.J.; et al. Guidelines for the diagnosis and management of food allergy in the United States: Report of the NIAIDsponsored expert panel. J. Allergy Clin. Immunol. 2010, 126, S1-S58. [CrossRef]

32. Sampson, H.A. Update on food allergy. J. Allergy Clin. Immunol. 2004, 113, 805-819. [CrossRef] [PubMed]

33. Asher, M.I.; Montefort, S.; Bjorksten, B.; Lai, C.K.; Strachan, D.P.; Weiland, S.K.; Williams, H.; Group, I.P.T.S. Worldwide time trends in the prevalence of symptoms of asthma, allergic rhinoconjunctivitis, and eczema in childhood: ISAAC Phases One and Three repeat multicountry cross-sectional surveys. Lancet 2006, 368, 733-743. [CrossRef]

34. Beasley, R. Worldwide variation in prevalence of symptoms of asthma, allergic rhinoconjunctivitis, and atopic eczema: ISAAC. The International Study of Asthma and Allergies in Childhood (ISAAC) Steering Committee. Lancet 1998, 351, 1225-1232. [CrossRef]

35. Simonsen, A.B.; Johansen, J.D.; Deleuran, M.; Mortz, C.G.; Sommerlund, M. Contact allergy in children with atopic dermatitis: A systematic review. Br. J. Dermatol. 2017, 177, 395-405. [CrossRef]

36. Hamann, C.R.; Hamann, D.; Egeberg, A.; Johansen, J.D.; Silverberg, J.; Thyssen, J.P. Association between atopic dermatitis and contact sensitization: A systematic review and meta-analysis. J. Am. Acad. Dermatol. 2017, 77, 70-78. [CrossRef] 
37. Williams, H.; Stewart, A.; von Mutius, E.; Cookson, W.; Anderson, H.R.; International Study of Asthma and Allergies in Childhood (ISAAC) Phase One and Three Study Groups. Is eczema really on the increase worldwide? J. Allergy Clin. Immunol. 2008, 121, 947-954.e15. [CrossRef]

38. Flohr, C.; Mann, J. New insights into the epidemiology of childhood atopic dermatitis. Allergy 2014, 69, 3-16. [CrossRef] 